\title{
KONSEP ETIKA PRODUKSI MENURUT PEMIKIRAN MUHAMMAD NEJATULLAH SIDDIQI
}

\author{
Mega Silvia ${ }^{1}$, Yadi Janwari², Ayi Yunus Rusyana ${ }^{3}$ \\ ${ }^{1,2,3}$ Program Studi Magister Hukum Ekonomi Syariah, Program Pascasarjana UIN Sunan \\ Gunung Djati Bandung \\ E-mail: megasilvia9f@gmail.com
}

\begin{abstract}
Abstrak
Etika produksi yakni unsur paling penting dalam sistem atau proses ekonomi, karena dalam produksi diatur mengenai apa saja yang boleh diproduksi dan bagaimana pemanfaatan etika produksi supaya bisa dimanfaatkan manusia untuk memenuhi kebutuhannya, sebuah masalah yang dirasakan umat Islam kini jika dihadapkan dengan sistem perekonomian kontemporer bebas nilai berupa sistem perekonomian sosialis beserta kapitalis. Pembuatan artikel ini tujuannya guna mengetahui bagaimanakah pemikiran Muhammad Nejatullah Siddiqi terkait etika produksi dan bagaimanakah faktor produksi sesuai pandangan Muhammad Nejatullah Siddiqi. Metode kepustakaan (library research) digunakan dalam penelitian ini melalui pendekatan kualitatif yakni sebuah teknik pengumpulan data dari buku, jurnal, artikel maupun internet yang berhubungan dengan permasalahan yang dikaji. Hasil penelitian menyatakan bahwa pemikiran Muhammad Nejatullah Siddiqi bisa dipahami keadilan dalam produksi yakni memposisikan nilai keadilan melalui memanfaatkan dan cara memproduksi berbagai barang atas kebutuhan manusia secara halal, karena melalui upaya ini mereka mendapatkan kekayaan dan meningkatkan taraf kehidupan.
\end{abstract}

Kata Kunci: Etika, Pemikiran, Produksi, Muhammad Nejatullah Siddiqi.

\section{Abstract}

The ethics of production is the most important element in a process or in an economic system, because in production it is regulated how the use of production ethics and what can be produced in order to be utilized by humans in meeting their needs, a very big problem felt by Muslims today when faced with a contemporary economic system that is free of value, namely capitalist and socialist economic systems. The purpose of writing this article is to find out how Muhammad Nejatullah Siddiqi thought about the ethics of production and how the factors of production according to Muhammad Nejatullah Siddiqi. The research method used by the author is a library research method with a qualitative approach that is a technique of collecting data from books, journals, articles and the internet related to the problems studied. The results stated that Muhammad Nejatullah Siddiqi's thoughts can be understood justice in production that is to put the value of justice by producing and utilizing goods in a circle that is halal to the needs of humans, because in this way they improve the standard of living and obtain wealth.

Keywords: Ethics, Thought, Production, Muhammad Nejatullah Siddiqi.

\section{A. PENDAHULUAN}

Syariat Islam memiliki sifat yang umum, dimana meliputi beberapa bidang kehidupan manusia yang bisa dilihat bahwa seluruh amal manusia sangat berkaitan erat dengan berbagai ketetapan hukum syari'at yang ada di al-Qur'an serta al- Hadist ataupun di luar keduanya berupa beberapa pendapat dari sumber lainnya yang diakui syari'at (Yahya \& Faturrahman, 
1986). Produksi sangat berarti dan merupakan bagian yang krusial dalam menentukan seberapa makmurnya bangsa serta tingkat penghidupan masyarakatnya. Selain itu, baik sunnah ataupun al-Qur'an juga memberi penekanan besar atas produksi kekayaan.

Muhammad Nejatullah Siddiqi (1995), dalam pendekatannya terkait produksi menyatu dalam paradigma neoklasif, perubahan yang diuraikannya yaitu dalam sistem perekonomian Islam, manusia sangat berkaitan dengan Islamic Man, dimana transformasi yang paling dasar ini dinyatakan akan merubah norma perilaku dan tujuan produksi produsen. Menurutnya, optimalisasi laba tidaklah motif satu-satunya serta tidak juga motif utama dalam produksi yang ada, namun Siddiqi menerangkan bahwa keanekaragaman yang meliputi optimalisasi laba dengan memberlakukan harga terjangkau bagi barang esensial, produksi kebutuhan dasar warga yang menciptakan employment, dan dengan memperhatikan masalah amanah (kepentingan masyarakat). Siddiqi (1995), juga menjelaskan terkait tujuan utama perusahaan, persediaan bagi keturunan ataupun layanan sosial, pemenuhan kebutuhan individu mencukupi tanggungan keluarga, sumbangan di jalan Allah, dan persediaan untuk menghadapi berbagai kemungkinan di masa mendatang. Diharapkan mempunyai sikap menjunjung tinggi kepentingan orang lain serta tidak sebatas mengejar laba yang tinggi, produsen memproduksi suatu jumlah tertentu untuk mendapatkan laba minimum yaitu cukup untuk mempertahankan kehidupan di lokasi lainnya, terkait ini Siddiqi mempergunakan istilah laba yang memuaskan.

Bila optimalisasi laba bukanlah motif utama ataupun terdapat perbedaan arti dari konsep rasionalitas dengan kerja sama dengan produsen lainnya yang tujuannya mewujudkan suatu tujuan sosial akan menjadi norma, dengan demikian memaksa terdapatnya akses lebih banyak atas informasi pada sistem perekonomian Islam. Kebutuhan pokok akan ditingkatkan produksinya, barang mewah akan minimal, serta barang haram tidak akan diproduksi sedangkan praktik perdagangan yang jujur akan didukung pahala, satu kalipun bahwa tiap produsen secara pribadi di asumsikan sudah mempunyai sifat yang diharapkan sesuai pedoman keadilan serta kebajikan. Negara diharap dapat mengawasi berlakunya kejujuran di pasar dan menjamin penyediaan keperluan dasar (Siddiq, 1995).

Selain tujuan yang hendak dikejar dan perubahan norma perilaku, Siddiqi tetap menjelaskan bahwasanya melalui kekuatan sendiri pasar tidak bisa memberikan jaminan distribusi kekayaan dan pendapatan secara adil serta campur tangan negara, berdasar hal ini sangatlah diperlukan meskipun Siddiqi memberikan perhatian yang lebih pada produksi selain tujuan yang diinginkan dan modifikasi perilaku, secara dasarnya analisnya tersebut merupakan neoklasik dengan pertimbangan utama berupa transformasi agen ekonomi menyangkut bekerjanya produsen dalam sistem ekonomi Islam. Bila bekerja dilakukan sesuai kaidah Islam, maka produsen tidak akan ada yang mempergunakan kekuatannya dalam memanipulasi maupun mendapatkan posisi untuk memenuhi keinginan pribadinya, bila produsen mau melakukan produksi di bawah maksimumnya tingkat laba, maka mungkin profit margin yang didapatkan rendah.

Fakta semacam ini tentu memunculkan suatu pertanyaan yakni terkait investasi dan akumulasi untuk pertumbuhan perekonomian, serta pola produksi semacam ini akan sebanding pula dengan permintaan, sebab Siddiqi sudah menjelaskan bahwa redistribusi sumber daya penting untuk kepentingan kaum miskin. Kondisi tersebut dapat mempengaruhi naiknya permintaan akan barang esensial. Akan tetapi, dampak tersebut sebatas bersifat jangka pendek, yakni mencari untung maksimal melalui mengatur efisiensi pemakaian faktorfaktor produksi, dengan demikian upaya mengoptimalkan untung bisa dicapai melalui langkah yang terefisien. Tiap perusahaan dalam praktiknya memaksimalkan untung, belum tentu dijadikan tujuan satu-satunya, lebih dari itu dimana pengusaha muslim terikat aspek tertentu untuk melaksanakan produksi. 
Sehingga bisa dinyatakan bahwa antara konsumen dan produsen saling bergantung. Produsen akan berupaya mempergunakan berbagai faktor produksi yang tersedia guna melakukan produksi barang kebutuhan seperti yang pelanggan minta. Sehingga ketika memproduksi barang kebutuhan itu, produsen mengharapkan supaya pelanggan melakukan pembelian barang yang diproduksi dengan harga melampaui biaya produksi (mencakup pula pemasaran/promosi) yang sudah produsen keluarkan. Selisih dari hasil yang konsumen harapkan tersebut adalah untung yang akan didapatkan. Produsen sewajarnya senantiasa memiliki prinsip memaksimalkan untung yang didapatkan melalui melakukan produksi barang berbiaya rendah (Rahman, 1995).

Masalah utama yang dihadapi untuk konsumen ialah cara mengatur barang kebutuhan yang diperlukannya. Sehingga konsumen tentu harus memprioritaskan jasa dan barang yang dibutuhkan, dimana ini sangat dipengaruhi oleh kondisi konsumen itu sendiri. Konsumen juga cenderung memperoleh barang berharga relatif murah. Fungsi dari Islam adalah sebagai norma perdagangan, ide kebajikan dan keadilan, serta mencela usaha dengan tujuan satusatunya berupa memaksimalkan untung.

Berdasar penjelasan tersebut, maka penulis mengangkat judul tentang: "Konsep Etika Produksi Menurut Pemikiran Muhammad Nejatullah Siddiqi”.

\section{B. METODE}

Penelitian kepustakaan (library research) ditetapkan menjadi jenis penelitian ini dengan memanfaatkan pendekatan kualitatif. Data penelitian dikumpulkan oleh penulis dengan teknik untuk menemukan serta melakukan pencatatan bahan kepustakaan dengan tujuan menghimpun informasi yang relevan menyangkut permasalahan penelitian. Data diolah dengan cara melakukan penyusunan serta pengklasifikasian bahan dan juga menarasikan sesuai kebutuhan dalam bahasan. Beberapa data yang telah didapatkan selanjutnya dilakukan analisis menggunakan metode analisis deskriptif.

\section{HASIL DAN PEMBAHASAN}

\section{Biografi Muhammad Nejatullah Siddiqi}

Muhammad Nejatullah Siddiqi sangat berkontribusi besar dalam perkembangan ekonomis Islam khususnya periode komtemporer kini dimana beliau juga termasuk tokoh ekonomi Islam dari mazhab mainstream (Chamid, 2010). Lahir di Gorakhpur, India 1931. Siddiqi dan berkuliah di Aligarh Muslim University. Beliau menganyam pendidikan di Azamgarh tepatnya di Madrasatul Islah, Saraimir dan juga adalah siswa dari Sanvi Dasgah Jamaat-e-Islami Hind, Rampur.

Karir Siddiqi diawali ketika dirinya menjabat menjadi Profesor Ekonomi di Universitas King Abdul Aziz Jeddah serta sebagai Profesor Studi Islam dan Associated Ekonomi di Aligarh University juga merupakan pelopor pendiri International Center for Research in Islamic Economy. Selanjutnya beliau menjabat di University of California, Los Angeles sebagai fellow di Center for Near Eastern Studies. Sesudahnya, menjadi pengawas sarjana di Jeddah, tepatnya di Islamic Development Bank, Islamic Research dan Training Institute.

Siddiqi adalah ekonomi India yang mendapatkan penghargaan dalam bidang studi Islam dari King Faisal International Prize. Beliau memperoleh pula penghargaan lainnya di bidang pendirikan misalnya, Islamic Movement in Modern Times (1995), Muslim Personal Law (1971), A Profilic Writer in Urdu on subjecta as Islami Adab (1960), serta Shah Waliullah Award in New Delhi (2003).

Karya ilmiah Siddiqi yang sudah dicetak dan dipublikasikan secara luas di antaranya yakni: Islamic Banking and Finance in Theory and Practice: A Survey of the Art (2006), Riba, Bank Interest and The Rationale of its Prohibition (2004), Dialogue in Islamic 
Economics (2002), Islamic Public Economics (2001), Economics, An Islamic Approach (2001), Role of State In Islamic Economy (1996), Theaching Economic in Islamic Perspective (1996), Insurance in an Islamic Economy (1985), Partnership and Profit-Sharing in Islamic Law (1985), Issues in Islamic Banking (1983), Banking Without Interest (1983), Muslim Economic Thinking (1981), Contemporary Literature on Islamic Economics (1972), Economic Enterprise in Islam (1972), Some Aspects of the Islamic Economy (1972), Muslim Personal Law (1972), serta Recent Theories of Profit, A Critical Examination (1971) (Arayik, 2014).

\section{Konsep Etika Produksi}

Secara etimologi, etika memiliki asal kata "Ethos" (bahasa Yunani), dimana ini artinya adat kebiasaan atau watak kesusilaan. Biasanya etika erat kaitannya dengan perkataan moral dimana ini adalah istilah dari "Mos" (bahasa Latin) serta bentuk jamak dari ini adalah "Mores" dengan arti cara hidup atau adat kebiasaan seseorang dengan berbuat baik serta menghindari berbagai perilaku buruk. Moral dan etika hampir mempunyai definisi sama, tetapi ada perbedaan pada keseharian, yakni moralitas atau moral untuk penilaian atas tindakan yang dijalankan, sementara etika ialah untuk pengkajian keberlakuan sistem nilainilai. Istilah lainnya yang mirip dengan etika yakni susila (Sansekerta) dimana ini cenderung menekankan pada aturan hidup (sila), prinsip, serta dasar-dasar yang lebih baik. Arti dari akhlak (Arab) adalah moral, serta arti dari etika yakni ilmu akhlak. Terkait ini, etika dinilai menjadi cabang filsafat yang secara spesifik mengkaji terkait nilai buruk dan baik dari tindakan seseorang (Zubair, 1995).

Prinsip etika dalam produksi yang harus tiap muslim lakukan baik komunitas ataupun individu ialah mengacu kepada seluruh yang dihalalkan Allah serta sesuai batas. Namun kebanyakan jiwa manusia cenderung kurang puas akan hal tersebut meskipun berjumlah banyak, sehingga ditemukan jiwa manusia yang cenderung tergiur akan hal-hal yang haram dengan menyimpang dari hukum Allah. Dijelaskan pula bahwasanya siapa yang melawan hukum Allah maka termasuk zalim.

Produsen dalam tatanan perekonomian konvensional secara dasarnya tidak mengetahui istilah haram maupun halal, dimana prioritas kerja mereka yaitu memuaskan keinginan melalui mengumpulkan harta, uang, serta laba. Manusia cenderung tidak mementingkan hal-hal yang diproduksinya tersebut apakah etis atau tidak, buruk atau baik, maupun berbahaya atau bermanfaat.

Produksi yakni menghasilkan kekayaan secara memanfaatkan sumber alam oleh manusia. Produksi adalah hasil upaya manusia yang artinya tidak membuat barang dari yang belum ada, namun produksi artinya melakukan perubahan wujud ataupun mengembangkan bahan alam maka mempunyai sifat yang bisa mencukupi kehidupan manusia baik jasa ataupun barang.

Berdasarkan pengertian lainnya, produksi merupakan semua upaya manusia membuat ataupun menambah guna sebuah benda. Produksi aktivitas menciptakan, aktivitas berarti bisa memenuhi kebutuhan manusia, jadi jasa ataupun benda yang meliputi seluruh aktivitas dan upaya dari meningkatkan kegunaan seperti memperdagangkan, menanam padi, kebutuhan pada jasa dan barang tersebut tidak terbatas ketersediaannya ataupun memiliki maksud lain antar kebutuhan tidak ada kesesuaian, sehingga muncul permasalahan untuk manusia yakni bagaimana manusia mencukupi kebutuhan yakni jasa maupun benda yang tidak terbatas tersebut.

Berdasar penjelasan tersebut, definisi produksi tidak terbatas dalam menciptakan kegunaan sebuah barang pada upaya menambah derajat kehidupan publik, produksi merupakan bidang yang haruslah mengalami perkembangan sesuai dengan perkembangan teknologi, dimana produksi adalah sebuah jalinan timbal balik yang sangatlah kuat dengan 
teknologi, teknologi dengan produksi saling bergantung, kebutuhan produksi guna berjalan memiliki biaya kecil, menambah produktivitas maupun memperbanyak dan menciptakan terobosan baru.

Berdasarkan sistem perekonomian Islam, kata "Produksi" adalah salah satu yang sangatlah diperlukan manusia, berdasar gagasan serta konsep produksi dijelaskan jika tujuan dasar yang akan diwujudkan aktivitas perekonomian diteorisasikan sistem perekonomian Islam yakni bagi kemaslahatan, seseorang maupun kemaslahatan dengan seimbang.

Dalam mencapai kemaslahatan masyarakat serta individu, sistem perekonomian Islam memberikan sejumlah landasan teoritis, yakni jaminan sosial, keadilan perekonomian, pendayagunaan sumber daya ekonomi efisien dan produktif (Mawardi, 2007).

Ketika melaksanakan produksi sangatlah dibutuhkan etika, sebab etika merupakan kemauan produksi yang murni untuk membantu inividu lainnya, kejujuran serta tidak berbuat curang, misalnya sangat banyak kecurangan yang muncul sekarang ini, hal ini yang disebut etika bisnis yang memproduksi yang diarahkan pada masyarakat luas supaya memiliki sikap tulus dan jujur untuk menghasilkan produk, maka setiap pihak tidak ada yang merugi sebab masing-masing rancangan produk tidak bisa dilepaskan dari penilaian etika.

Muhammad Nejatullah Siddiqi menyebutkan jika sistem produksi pada Islam haruslah dikontrol oleh kriteria objektif dan subjektif, kriteria yang objektif bisa terlihat pada wujud kesejahteraan, yang bisa dinilai menggunakan uang sedangkan kriteria objektif pada bentuk kesejahteraan yang bisa dinilai melalui segi etika, perekonomian yang disesuaikan terhadap anjuran kitab suci al-Qur'an maupun sunnah, maka pada Islam keberhasilan suatu sistem perekonomian bukan hanya dilandaskan melalui semua hal yang sifatnya materi saja, namun bagaimanakah supaya masing-masing kegiatan perekonomian misalnya produksi dapat mengimplikasikan nilai etika, norma ataupun memiliki maksud lain yakni akhlak yang terpuji ketika melakukan produksi, maka tujuan kemaslahatan umum dapat terwujud menggunakan kegiatan produksi yang ideal (Qardawi, 1997).

Beberapa ahli ekonomi menyebutkan produksi yakni menghasilkan kekayaan secara mendayagunakan sumber alam oleh manusia. Sumber alam manusia merupakan kekayaan alam yang diciptakan Allah guna manusia yang memiliki beragam jenis, pertama lapisan bumi memiliki unsur yang tidak sama, seperti lapiran udara ataupun beberapa jenis gas, yang membedakan Islam dengan materialisme yakni jika Islam tidak pernah memisahkan ilmu dengan akhlak, etika dan politik, etika dna perang serta kerabat sedarah daging dengan kehidupa Islam.

Islam merupakan risalah yang diturunkan Allah lewat Rasul guna memperbaiki ahlak manusia, Nabi SAW bersabda: "Sesungguhnya aku di utus untuk menyempurnakan ahlak mulia, Islam juga tidak memisahkan agama dengan negara dan materi dengan spritual sebagaimana yang di lakukan eropa dengan konsep sukalarisme nya, Islam juga berbeda dengan konsep kapitalisme yang memisahkan akhlak dengan ekonomi".

Manusia muslim kelompok ataupun perseorangan pada lapangan ekonomi dan bisnis, pada satu sisi diberikan kebebasan dalam mencari laba sebanyak mungkin, tapi pada sisi lainnya dia terikat dengan etika dan iman maka dia tidak bebas dan harus menanamkan modal ataupun membelanjakan harta. Penduduk muslim tidak bebas jika tidak ada kendali untuk memproduksi semua sumber daya alam, menyalurkan serta mempergunakannya, dia terikat dengan etika dan kaidah mulia.

Faktor Produksi berdasar penguraian Muhammad Nejatullah Siddiqi (1995), diantaranya sebagai berikut:

a. Alam

Alam adalah faktor produksi yang utama maupun pertama, faktor alam mencakup seluruh isinya yakni: 
1). Tanah

Tanah memiliki arti yang luas meliputi seluruh sumber yang kita dapatkan melalui gunung, laut, udara, hingga yang memiliki kondisi geografis, iklim, angin yang termuat didalamnya, al-Qur'an mempergunakan benda yang sifatnya keduniaan, diciptakan untuk manfaat mereka.

2). Bumi (tanah)

Tidak bisa dipungkiri jika faktor produksi yang terpenting yakni permukaan tanah yang diatasnya kita bisa bekerja, berjalan, membangun rumah, dan melaksanakan apapun sesuai keinginan kita, al-Qur'an memberi peringatan bahwasanya mansia diberikan tempat tinggal maupun kesenangan di bumi.

3). Mineral

Bumi ini memiliki banyak sumber mineral yang bisa dipergunakan manusia pada produksi dan memperoleh kekayaan lebih banyak.

4). Gunung

Gunung adalah sebuah sumber lainnya yang dijadikan sumber tenaga asli yang memudahkan untuk mengeluarkan kekayaan, al-Qur'an selalu membahas terkait gunung dan manfaatnya yang musahabah bagi manusia.

5). Hutan

Hutan adalah sumber kekayaan yang sangatlah krusial, hutan menyediakan bahan bangunan, bahan bakar maupun bahan mentah guna perkapalan, kertas, perkakas rumah tangga maupun industri lainnya yang jumlahnya sangat banyak.

6). Hewan/Binatang

Hewan memiliki banyak manfaat untuk manusia mereka memberi susu, daging, lemak untuk makanan. Memberi bulu pula, kulit, tulang guna dipakai bagi kebutuhan perekonomian yang lain, misalnya industri maupun tujuan yang berkaitan dengan perhiasan, beberapa ternak itu menjadi alat transportasi.

b. Tenaga Kerja

Kerja merupakan semua ikhtiar dan upaya yang dilaksanakan anggota badan ataupun pikiran guna memperoleh imbalan yang layak, misalnya jenis kerja yang dilaksanakan secara pikiran ataupun fisik, pekerja menjadi faktor produksi memiliki arti penting, sebab seluruh kekayaan alam tidak bermanfaat jika tidak diolah manusia. Berdasarkan sistem Islam sangatlah mempertimbangkan hak pekerja dan itu haruslah diperhatikan pada tenaga kerja yaitu:

1). Buruh haruslah mendapatkan upah yang selayaknya supaya bisa merasakan derajat hidup yang baik.

2). Mereka haruslah membayar ganti kerugian kecelakaan yang cukup saat bekerja. Ketetapan yang wajar haruslah diciptakan guna pembayaran pensiunan lanjut usia,

c. Modal pekerja, penguasa bisa diminta guna berkontribusi menjadi modal bantuan.

Modal adalah aset yang membantu mendistribusikan kekayaan selanjutnya. Milik negara ataupun seseorang yang dipakai guna menghasilkan, kemudian selain yakni modal modal bisa memberi kepuasan pribadi ataupun membantu menghasilkan asset lebih besar. Seperti dinyatakan Muhammad Nejatullah Siddiqi (1995) "Modal adalah faktor produksi yang menghasilkan kekayaan tanpa modal produksi yang berskala besar dalam dunia industri modern menjadi tidak mungkin, sebab jika dengan tenaga kerja manusia saja hasilnya sangat sedikit karena itu tidak salah jika di katakanbahwa kemajuan industri abad ini karena penggunaan modal".

\section{Analisis Konsep Etika Produksi Menurut Muhammad Nejatullah Siddiqi}


Etika produksi adalah elemen kunci yang tidak bisa terpisahkan dengan semua kegiatan perekonomian. Oleh karenanya bisa dilaksanakan jika memproduksi sebuah barang adalah kewajiban yang bisa memberi dampak baik pada kehidupan sehari-hari, baik masyarakat ataupun perseorangan. Sesuai pemaparan Muhammad Nejatullah Siddiqi guna mencapai keadilan itu Islam memberi tekanan lebih kepada pembersihan maupun pemurnian untuk menegakkan sistem kehidupan yang setara. Dia menyatakan pula memproduksi harta benda supaya tidak ketinggalan dari individu lainnya merupakan sebuah kewajiban, Islam tidak memberi kebebasan tanpa batas pada usaha perekonomian.

Pandangan Muhammad Nejatullah Siddiqi (1995) terkait etika produksi pada sistem perekonomian Islam sesuai prinsip perekonomian yang mengharapkan sistem ekonomi yang adil selaras dengan sunnah serta al-Qur'an, yang mana islam mengharapkan pula produksi jasa dan barang yang halal, tidak membuat rusak fitrah manusia, tidak menganiaya pula, yang bertujuan guna memperjuangkan kebutuhan hidup manusia dan mencari kebahagiaan akhirat yang diridhoi Allah SWT. Sehingga saya sangatlah setuju dengan pandangan Muhammad Nejatullah Siddiqi sebab ketika melaksanakan produksi sangatlah dibutuhkan etika sebab etika tersebut penting untuk umat manusia ataupun untuk karyawan sementara berdasar ahli ekonomi, sistem etika tersebut memiliki kecenderungan menunjukkan perjalanan yang dinamis dengan perilaku yang selalu mengalami perubahan dan sifatnya sementara selaras dengan dinamika peradaban yang mendominasi sebab diketahui sekarang ini cara penggunaan etika tersebut menurun sebab beberapa karyawan lebih suka karyawan yang kurang memiliki etika,

Maka tujuan terpenting yakni memberi kebebasan pada seluruh individu pada bidang perekonomian, namun harus memiliki etika, sebab etika pada produksi ini haruslah betulbetul dipergunakan untuk memproduksi kebutuhan masyarakat dan dilarang berbuat curang. Ini jelas tidak diperbolehkan seperti ditegaskan al-Qur'an di surat an-Nisa ayat 29-30:

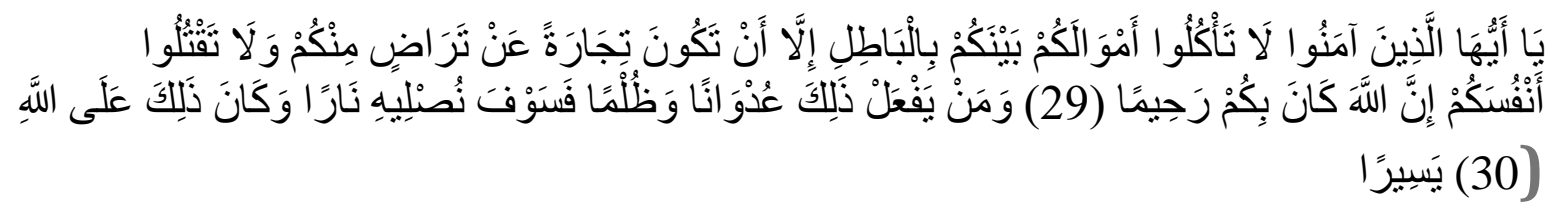

Artinya: "Hai orang-orang yang beriman, janganlah kamu saling memakan harta sesamamu dengan jalan yang batil, kecuali dengan jalan perniagaan yang berlaku dengan suka sama-suka di antara kamu. dan janganlah kamu membunuh dirimu Sesungguhnya Allah adalah Maha Penyayang kepadamu. Dan barangsiapa berbuat demikian dengan melanggar hak dan aniaya, Maka kami kelak akan memasukkannya ke dalam neraka. yang demikian itu adalah mudah bagi Allah."

Berdasar penguraian Muhammad Nejatullah Siddiqi (1995), ayat al-Qur'an di atas tidak memperbolehkan seseorang mendapatkan kekayaan secara curang dan memberi peringatan pada orang yang berbuat pelanggaran menggunakan kata-kata, jangan membunuh individu lainnya, bila orang memperoleh kekayaan menggunakan cara salah, sehingga bukan hanya merusak upayanya sendiri namun pula memunculkan kondisi yang tidak diharapkan, karena tindakan salah dan curang akan merusak sistem perekonomian.

\section{KESIMPULAN}

Sesuai pemaparan Muhammad Nejatullah Siddiqi, ayat al-Qur'an di atas tidak memperbolehkan seseorang mendapatkan kekayaan secara curang ataupun memperingatkan seseorang yang berbuat penyimpangan menggunakan kata-kata, jangan membunuh individu lainnya, bila orang memperoleh harta kekayaan menggunakan cara salah, sehingga bukan hanya merusak upayanya sendiri namun pula memuculkan kondisi yang tidak dikehendaki, karena tindakan curang maupun tidak benar bisa merusak sistem perekonomian. Sehingga 
Islam memilih langkah yang dibutuhkan dalam menerapkannya kepada bidnag produksi serta pendidikan moral akan meningkatkan rasa bertanggung jawab antar orang, karena jika mempunyai moral dan etika akan memunculkan karakter yang luhur maupun kepercayaan padanya. Norma penting untuk berproduksi sesudah wajib bekerja yakni, tekun ketika bekerja, Islam tidak menginginkan umatnya hanya bekerja, namun pula memerintahkan supaya mereka bekerja secara baik dan tekun. Dengan terdapatnya prinsip etika produksi yang implementatif ada pada prinsip keadilan, tauhid, kemanusiaan, kebajikan, dan prinsip tanggung jawab serta kebebasan. Penerapan prinsip etika produksi ini akan memberi pengaruh pada derajat perkembangan perekonomian, keadilan serta pemerataan distributif, tanggung jawab sosial produsen, kelestarian lingkungan hidup.

\section{DAFTAR PUSTAKA}

Aravik, H. (2014). Sejarah Pemikira Ekonomi Islam Kontemporer. Depok: Kencana Prenada Media Goup.

Chamid, N. (2010). Jejak Langlah Sejarah Pemikiran Ekonomi Islam. Yogyakarta: Pustaka Pelajar.

Departemen Agama Republik Indonesia. (1989). Al-Qur'an. Semarang: Toha Putra.

K. B. ITB. (1988). Ekonomi. Bandung: Ganeca.

Mawardi. (2007). Ekonomi Islam. Pekanbaru: Riau Graha UNRI Press.

Qardawi, Y. (1997). Norma dan Etika Ekonomi Islam. Jakarta: Gema Insani.

Rahman, A. (1995). Doktrin Ekonomi Islam. Yogyakarta: Dana Bakti Wakaf.

Siddiqi, M. N. (1995). Kegiatan Ekonomi Dalam Islam. Jakarta: Pustaka Firdaus.

Yahya, M., \& Faturrahman. (1986). Dasar-Dasar Pembinaan Hukum Fiqh Islam. Bandung: al Ma'arif.

Zubair, A. C. (1995). Kuliah Etika. Depok: Rajawali Press. 